\title{
Adaptation Strategies of Relocated Persons in Flood Affected Areas: The Case of the Ciliwung River area in Jakarta, Indonesia
}

\author{
Doris Kokutungisa Ishenda \\ School of Public Administration, Hohai University, Nanjing, China \\ E-mail: Ishenda@yahoo.co.uk
}

Shi Guoqing

School of Public Administration, Hohai University, Nanjing, China

Received: November 21, 2019 Accepted: February 6, 2020 Published: February 11, 2020

doi:10.5296/ijgs.v4i1.16446

URL: https://doi.org/10.5296/ijgs.v4i1.16446

\begin{abstract}
This study discusses the adaptation of displacees due to the Ciliwung River normalization displacement program carried out by the Daerah Khusus Ibukota (DKI) which is a special region of the capital city of the Jakarta provincial government that intends to address the problem of flooding that occurred in the capital city of Jakarta. There is a change in displacees, namely: a reduction in income as well as an increase in expenses for the rental of a low-cost flat, water and electricity. The concept used in this study is Suharto's concept of an adaptation strategy in which there are three strategic points, including active strategy, passive strategy and social network strategy. The concept was chosen because it was adapted to the habits of the Indonesian people themselves. The method used is a case study with the technique of determining the informants by snowball sampling. The results showed that displacees carried out Suharto's overall adaptation strategy.
\end{abstract}

Keywords: Displacement, Relocation, Survival strategies

\section{Introduction}

The floods that occurred in Jakarta were caused by narrowing and silting of the Ciliwung River in the area due to people building houses along the riverbanks and the habit of throwing garbage into the river. Gunawan (2010) mentions "The canal system does not work because 
Jakarta's topography is flat so water cannot flow gravitatively". Sedimentation of mud and rubbish also causes the water flow not to be smooth. Flood control with the construction of canals is only able to reduce the flood burden temporarily. Therefore, the DKI Jakarta government plans to overcome the problem of flooding by carrying out the Ciliwung river normalization program and relocating communities living along the river to inhabit a Rusunawa (public apartment unit, with rental arrangement). The normalization plan is contained in Regional Regulation (Perfa) Number 1 of 2012 concerning Spatial Planning in 2030 and Regional Regulation Number 1 of 2014 concerning Spatial Detailed Plan (RDTR).

Following completion of the relocation, a new problem emerged, namely the people affected by the eviction were finding it more difficult to continue their livelihood (Ainurrofiq, 2018). Being relocated to Rusunawa resulted in limited access to transportation for going to school, getting health services and other daily tasks (Puput \& Chen, 2018). A study conducted by the Jakarta Legal Aid Institute (LBH), found that the total number of people who had permanent jobs and were relocated decreased from the previous 33.4 percent while still in their previous dwellings to 29.2 percent after being relocated to Rusunawa (Muhammad et al , 2016). Most of the displacees' work is in the informal sector, such as tofu production, operating food stalls, trading grocery items, or operating a motorbike repair shop, which is generally done in their own homes (Elyda, 2017). Workers have to travel long distances to reach the location of their old workplaces. Research conducted by LBH Jakarta also documented that the distance of their new residential flats to their workplaces has greatly increased. In addition, people who used to trade at their place of residence also now have to look for other jobs, because the resources they used to use to run their businesses are now less accessible. In addition, people cannot afford to pay monthly rent because Rusunawa provided by the DKI Jakarta provincial government requires displacees to pay monthly rent of around 300 thousand (Ni Made, 2017).There is no assistance from the DKI Jakarta Government as a form of compensation for residents affected by eviction. In some cases, residents of the Rusunawa residents are in arrears of rent up to a year since the first relocation. Displacees feel burdened with the rental costs because before being relocated, they paid no rent because they lived in their own homes, usually a house left by parents or family. Residents had difficulty accessing food needs in the Rusunawa environment resulting in increased household consumption costs. Displacees have to travel longer distances to get consumer goods every day, which also increases transportation costs. Displacees said that the price of food needs was much cheaper when they still occupied their old places of residence.

\subsection{The Theoretical Foundation of Survival Mechanism Theory}

Survival strategies are used by every society especially when confronted with something new in their lives. Conceptually, survival strategies are defined as activities of the poor to continue their lives when in difficult circumstances. Survival strategies refer to the activities of poor people in times of stress which they see as crucial for the continued running of their household. This focus concentrates on their own priorities (Beck, 1989). A survival strategy according to Snel and Staring (2001) is described as a series of actions chosen by individuals and households who are socially and economically poor. Some survival strategies, such as taking loans, selling assets, and migration, are relatively well recognized. Others identified 
during the collection of data are less so and will be discussed hereafter: use of common property resources (CPRs); changes in eating and food preparation; shared rearing of livestock; and mutual support networks. All these are mainly undertaken by women and children, and challenge the dominant view that the poor are passive. While extreme crises such as famine are met by sequences of survival strategies (Corbett, 1988), everyday survival strategies vary in relative importance at different times. They also interlink, but can be described separately. There are several theories or concepts that discuss survival strategies, but in this study the focus is on Suharto's theories which can be analyzed both economically and socially.

\subsubsection{Active Strategy}

An active strategy is an activity carried out by poor families by optimizing all the potentials of the family. The main purpose of this strategy is to look for additional income, by doing side jobs or by increasing work hours. Another way is to use existing family members to make a living, for example, a wife or child. For poor families, earning a living is not only the responsibility of the husband, but it is the responsibility of the whole family to be able to increase income and meet household needs

\subsubsection{Passive Strategy}

This strategy involves suppressing or minimizing family expenses. It is carried out by reducing family expenses; for example; the cost of daily food, shopping for clothes, education and others. In other words, this strategy requires family members to be more selective, not to buy items that are not needed for the fulfillment of family household needs.

\subsubsection{Social Network Strategy}

A network strategy is carried out by utilizing a family's social network. A network strategy utilizes social relations such as informal and formal kinships. For example, by borrowing money from neighbors, stalls or shops, moneylenders or banks, using poor community programs and so forth. When a family adopts a survival strategy, one of the possible ways is to look for a loan or capital to meet the necessities of life. This can be obtained through existing social networks. In social life, citizens may not attune from social networks; this is an important aspect for people who have shortcomings in economic terms. With the existence of extensive social networks, a person may be more apt to continue to survive.

\section{Research Methods}

To get more accurate results about the Rusunawa community's survival strategies, an instrumental case study method was used. The reason for using the instrumental case is because the problem of survival strategy is not a unique problem, every society in general must carry out a strategy to survive when faced with new environmental conditions. Researchers are interested in researching a survival strategy because it was an aftermath of the relocation of displacees from the slum area to Rusunawa. Snowball sampling, a type of random sampling method was used in this study. In this technique the first informant provides information and refers other knowledgeable individuals to the researcher for interviewing. 
Data collection techniques used in this study was observation, interviews, and documentation. Interviews and observations were conducted in a structured manner by providing a list of predetermined questions. Data analysis techniques used were matchmaking patterns, explanations, and time series analysis. Yin (2014) mentions the stages of matchmaking patterns are: making an initial proposition, comparing initial case findings with initial propositions, refining statements or propositions, repeating this process as many times as needed.

\section{Findings}

The displacement of displacees to Rusunawa requires adaptation so that the community can survive. Based on observations and interviews, the informants revealed that the social network strategy is a strategy that is used more frequently than the other two strategies. Displacees usually contact their close relatives when they need help or sudden costs. Most displacees say that they would prefer to seek loans from relatives rather than elsewhere, because they feel safer if they borrow from their siblings. Displacees tend to avoid borrowing from neighbors because it is feared that if displacees cannot afford repayment there will be conflict between neighbors.

\subsection{Relying on Social Relations}

From the results of interviews and observations it is known that the familial relationship between displacees and their family members is very close. This is evident from the fact that displacees' first line of contact for help is a family member when faced with problems. The power of relationships and ties can never be denied, however in many cases this also cannot be done directly (Beck, 1989). For some of them, asking for help from people outside the family is a moral problem. Due to displacement, their previous neighbors are scattered, they therefore do not feel comfortable asking for help from new neighbors:

"For me, it's family first, don't I still have a family? If there is anything, then it's the family first. I would go to the neighbors later, why is it difficult, the ones who understand themselves are not the same as family disgrace, so it's not good if the neighbors understand "(Baharudin, August 20th, 2019)

Some displacees also rely on loans from neighbors because they are far away:

"Yes, I usually seek help from neighbors. My family members are far away" (Nurhayati, August 21st, 2019)

While there are other options for borrowing money such as from banks and moneylenders, there are also problems associated with these options, such as convoluted procedures when borrowing from banks, while moneylenders provide high interest loans. Another option that is usually used by displacees is to take advantage of the existence of non-governmental organizations by appealing to the state administrative court regarding their claim for compensation for relocation from the government. This activity is accompanied by NGOs:

"We are helping to solve the problem of displacees that are in arrears, while the DKI Jakarta government does not want to know, those who do not pay are evicted and replaced by new 
residents, even though the reason for the residents being in arrears is because they have no income or lost their jobs. There are several other problems such as leaky flat housing, electricity and water, the cost of which always increases every month, with a price of IDR 53 thousand, it can only get $36 \mathrm{kwh}$. With this eviction problem, we have helped to bring to court PTUN court, but yesterday together with the displacees lost the case so we plan to appeal again "(LSSM, August 20th, 2019)

\subsection{Household Budgets and Consumption Patterns: Reducing the Cost of Daily Necessities}

Displacees utilize a passive strategy by reducing the number of meals taken in a day. Food stocks are thus expected to last longer. Changing patterns of eating and food preparation are less well known as a coping strategy than gathering. Cuts in consumption are an enforced part of the lifestyle of the poorest (Beck, 1989). Displacees suppress consumption expenditures per day. This is then allocated to pay rent, water and electricity bills. The money is usually allocated to try venture capital and the most important needs such as school fees. Eventually, should displacess encounter difficulties, they will then shift to a social network strategy to attempt to resolve the shortcomings"

"Usually, one kg of rice is used up a day, when my grandchildren come and ask for food, because their parents work, they come here to ask for food, for a side dish, maybe vegetables, tofu and tempeh, if there is a fortune yes sometimes eggs or chicken. We used to eat chicken more often when we were still living in the old place, now rarely, money is used for other needs, paying for electricity, water and rent"'(Mahmudah, August 22nd, 2019).

\subsection{Involvement of Family Members for Survival}

In addition to social networking strategies and passive strategies, the displacees also employ active strategies, involving other family members to look for additional income to meet their increasing daily needs:

"I opened a shop, my child works at a supermarket. My husband is gone, because the needs are now increasing, yes the cost of rent is the cost of electricity and water, my child usually works extra, take shifts of his friends who cannot come, will be given compensation in the future"(Nuamah, August 20th, 2019).

The active strategy is to keep their previous jobs, although sometimes they also have to work more to make more money. It is also known from interviews and observations that they do not force other family members to come to work. If there is a lack of funs, displacees are more likely to borrow money than forcing other family members to seek more income.

"What more work, what is there to go through, wanting to find work again also requires time and money, especially let alone if I have to leave my children (Sumiati, August 20th, 2019)

Most displacees also deliberately do not pay rent and water bills up to the maximum deadline and go into arrears. When the maximum time limit has come, they will pay, so they are not evicted. The unpaid money is used for venture capital so that it can generate additional profit for income. 


\section{Conclusion}

Some survival strategies, such as finding a loan, selling assets, and deciding to return home are usually more organized. Others, such as changes in eating and food preparation and helping each other is usually done more by women. Everyday survival strategies can differ depending on time and needs; however, these strategies are still related to each other (Corbett, 1988). All displacees engage in active strategies because they still maintain the same source of income while also seeking additional work. Another active strategy is to reduce the portion of the amount of food consumed, from three times a day to twice a day. The passive strategy used by displacees is to deliberately be in arrears in the rental of low-cost apartment buildings and divert funds to meet other needs, for example, to open new businesses or continue businesses in low-cost apartments. Finally, they use the social network strategy, even though displacees have diverted funds from rental for venture capital. All in all, these strategies all require time to restore livelihood. Therefore, when it comes to survival strategies depending on the reality of the situation, displacees tend to adapt and use all means possible to survive by utilizing all available resources. Whether it is active, passive or social, when need arises, all become relevant at some point and are not necessarily mutually exclusive. Sometimes they will need to put in the extra work themselves, sometimes they will need to subsidize and improvise and sometimes they will be forced to seek help from other friends and families within their social networks, all these just for the sake of recuperating. During or after relocation and resettlement, times for families are tough and many challenges are faced, hence it is important to understand the needs of these families and communities and for governments and investors to cater and provide for these displacees to the best of their capacity and ensure that the displacees' livelihoods are recovered, restored and improved.

\section{References}

Ainurrofiq, M. (2018). The impact of the relocation program of slum areas of the Kampong Pulo community to simple flats in West Jakarta, West Jakarta. Essay. Syarif Hidayatullah State Islamic University Jakarta.

Basrowu, K. (2004). Understanding Qualitative Research. Jakarta: Rineka Cipta.

Beck, T. (1989). Survival strategies and power among the poorest in a wes Bengal village. IDS Bulletin, 20(2). https://doi.org/10.1111/j.1759-5436.1989.mp20002004.x

Corhctt, L. (1988). Famine and household coping strategies. World Erelopotent, 6(9), 1099-1112. https://doi.org/10.1016/0305-750X(88)90112-X

Elyda, C. (2017). River Normalization to cause more evictions this year. The Jakarta Post.

Gunawan, R. (2010). Jakarta Flood Control from Time to Time. Jakarta: Kompas.

Ministry of Public Housing of the Republic of Indonesia. (2016). Rusunawa for relocation of residents of the Ciliwung riverbank.

Muhammad, A. H. (2016). Report on the Fulfillment of the Right to Adequate Housing for Victims of Forced Evictions in Jakarta that inhabit Flats. 


\section{Macrothink}

International Journal of Global Sustainability

ISSN 1937-7924 2020, Vol. 4, No. 1

Ni, M. W. W. (2017). Rusunawa sustainability assessment and the impact to residents' capabilities. Architecture, space management.

Puput, I. S., \& Chen, S. J. (2018). Impoverishment of Induced Displacement and Resettlement (DIDR) Slum Eviction Development in Jakarta Indonesia. International Journal of Urban Sustainable Development.

Snel, E., \& Staring, R. (2001). Poverty, migration, and coping strategies: an introduction. Focaal - European Journal of Anthropology, 38, 7-22

Suharto, E. (2009). Poverty and Social Protection in Indonesia. Bandung: Alfabeta.

Yin, R. K. (2014). Case Study Design \& Method. Jakarta: Rajagrafindo Persada.

\section{Copyright Disclaimer}

Copyright for this article is retained by the author(s), with first publication rights granted to the journal.

This is an open-access article distributed under the terms and conditions of the Creative Commons Attribution license (http://creativecommons.org/licenses/by/3.0/). 